\title{
THE STUDY OF TABOO AND EUPHEMISM ON THE ENGLISH DEPARTMENT STUDENTS IN UNIVERSITAS PAMULANG
}

\author{
Haryati ${ }^{1}$ \\ ${ }^{1}$ Universitas Pamulang
}

Corresponding Author: Haryati Safa, E-mail: haryati.safa@gmail.com

\begin{tabular}{l}
\hline ARTICLE INFO \\
\hline Received:2020-02-19 \\
Accepted: 2020-03-10 \\
Published: 2020-03-15 \\
Volume: 4 \\
Issue: 1 \\
DOI: \\
https://doi.org/10.33019/lire.v \\
3i2.60 \\
\hline KEYWORDS
\end{tabular}

Gender, taboo words, euphemisms, politeness, students' conversation

ABSTRACT

This study was aimed to find out the kinds of taboo and euphemism words among college students of faculty of letter at Universitas Pamulang, and the reasons why the students select to utter taboo or euphemisms. A descriptive qualitative approach was conducted in this research.

The respondents of this study were the fourth semester students (regular A class) taking the speaking 4 at English department of Pamulang University academic year 2018/2019. Out of 176 students of the population, 40 students (20 males and 20 females) will be chosen as the samples based on the purposive sampling. To collect the data, the writer used two kinds of instruments: an observation of students' speaking conversation and interview. These instruments were administered to answer stated research questions. As the results, the writer found that most male students preferred uttering taboo words, and the female students seemed to utter euphemism instead of taboo words. Female and male students produced more taboo words like kick the ass, abortion, hostess, nigger, four eyes, bloody, damn, gosh, fatty, toilet, idiot, homo, and others, and the students produced few euphemisms like a special need, working class, pass away, Black American, and story teller. The writer also found some factors of the use of taboo words such as gaining poor vocabulary, gaining poor language acquisition, expressing anger, showing power, being cool, and imitating other's utterances. Moreover, the factors of euphemism are reading habit and good language acquisition. Theoretically, the research finding would enrich the teachers' skills to introduce euphemism as a substitution to replace the use of taboo words in students' conversation and assist students to utter proper words in social situation that leads politeness.

\section{INTRODUCTION}

Language is media for communication in social life. Human beings use it wherever they go to socialize with others in whole human life. Social system is affected by several social factors: age, educational level, economy, and professions. One having high education low education will have diversity of language use. Meanwhile, communicative system, language use is affected by situational factors including topics, speakers, listeners, and the goals of conversation (Nababan, 1987).

Obviously, language play important role in people's culture. In social culture, people often argue a lot with others who have distinctive perception. In fact, this situation leads people to utter many slang and offensive words or taboo words. These words are used to express any kind of feeling 
guilty, hate, dissatisfaction, or disagreement of situation. Hence, as religious human beings, people must consider how someone show their words in polite way in any situation they face. As the Eastern country, people including the university students who are educated people must share their arguments in appropriate way in order not to hurt others. In addition, the words should be equivalent with the social norms and culture in societies, and they can be well accepted in communities.

Taboo as the expression to mock other people must be banned in social interaction since it leads to bad effects for others, and the taboo words breaks the social rules. However, there are communities who always utter taboo words to express their freedom in using language and to show their disagreement of some particular topics, or the popular term is the speaking freedom. Moreover, euphemism can be the best alternative way to avoid misunderstanding and not to hurt other people. If university students never utter euphemism, it leads to many negative effects in societies like feeling sad, depressed, stressed, and no respect each other. However, euphemism also delivers different meaning from the original word, for example, toilet is claimed as taboo word, and to soften the word, it is suggested to replace with comfort station. It seems weird, actually; therefore, some people are not able to catch the main point. Besides, euphemism can be used to respect other people in communication, and it is so appropriate way for students use them in academic situations to show that they educated people.

The significance of the study is intended to give some contributions to the development of language learning and specifically to students' utterances and politeness in social interaction. For teachers, the study can be beneficial guidance to enhance the students' speaking performance in a proper way and good manner in communication. Further researcher, it is supposed to be guidance to upgrade similar research. Academic institution, it is supposed to be good perception in order to enhance college students' attitude in communication. Based on the observation of the writer during the teaching and learning process in classroom, she found some English department students face several problems in communication relating to taboo and euphemism. In English department, the students joining the speaking class just utter the English expressions which they know without classifying the taboo or polite words. They just communicate with their own vocabulary mastery;

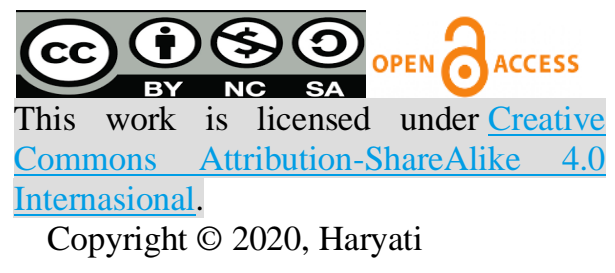


THE STUDY OF TABOO AND EUPHEMISM ON THE ENGLISH DEPARTMENT STUDENTS IN UNIVERSITAS PAMULANG

Lire Journal (Journal of Linguistics and Literature) P-ISSN: 2598-1803 E-ISSN: 2581-2130 Volume 4 Number 1 March 2020

therefore, it leads to misunderstanding among students. This case occurs because the students are not able to apply the proper words in certain situational conversation. They also prefer uttering those since the influence of digital media. They obtain many English words that are published through online media. The media promote them many taboo words, so it affects them a lot. Furthermore, there are other researchers who had conducted the study. Mahmuda (2003) investigated the use of taboo and euphemism on English conversation, and she found more taboo utterances expressed by the participants than euphemism. On the other hand, Abidin (2003) conducted the similar study and analyzed the use of taboo and euphemism on printed newspaper. As the result, he analyzed the types of euphemism and taboo utterances and found many euphemism utterances. All of the researchers above have similar interest in observing the taboo and euphemism, but they have different objects of the study. According to the previous explanation, the writer is interested in analyzing the taboo and euphemism word among university students because it is crucial for them to classify taboo and euphemism and to apply them in appropriate situational conversation.

\section{LITERATURE REVIEW}

\subsection{The Understanding of Taboo}

In general, taboo words have been using by Indonesian people, especially students in schools and universities. The usage of taboo words is encouraged by social environment and the growth of technology. They read printed media, and they access the electronic media to access a lot of information including movie and song which share many taboo words. In recently days, taboo words cannot be denied by students since those words have been familiar among them, and they think the words have no negative consequences in social interaction. Most of students talk taboo topics without considering the words choice.

Many scholars have defined the understanding of taboo and its topics. Fromkin (2005) define taboo as a prohibition of behavior that influence daily life, or it is forbidden to use in polite society; it also includes bodies function, sex, diseases, death, killing, and others. It is believed as aggressive and unpleasant word to be uttered in conversation. Taboo topics are including sex, Christian 94

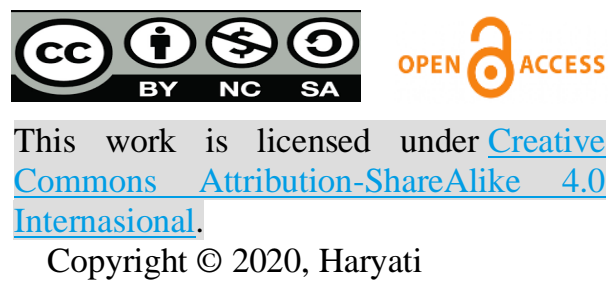


religion, abortion, death, and family (Ekstrom, 2008). To conclude, taboo is forbidden words to be uttered individual in social situation since it will harm and hurt someone and a group of people. Societies claim that it is not polite, rude, and appropriate words. Taboo words are insulting and not suggesting to utter. In Bahasa, people always hear some taboo words like sialan, babi, bangsat, menstruasi, and other words. Although those words are well known for Indonesia people, they should be eliminated due to some factors: religion, inappropriateness, and politeness. Moreover, the usage of taboo words will lead to embarrassment, anxiety, or injury to others, also it contaminates others. In brief, the usage of taboo is not allowed in conversational situation since it will harm others and create negative perception within societies. Wibowo (2008) highlights "the degree of violating the taboo is bigger among close or intimate relationship of breakers." It means that intimate friends will probably have opportunity in producing taboo utterances that causal friends or acquittance.

\subsection{The Understanding of Euphemism}

In people's daily activity, they have used metaphor to cover taboo words with the polite words. The kind of these words is called Euphemism. It is not well known as taboo words in societies. It is a word or phrase that can substitute taboo words to avoid unpleasant subjects, can replace taboo words to avoid fearful, misunderstanding, unpleasant, and it is more acceptable in social interaction (Habibi \& Khairuna, 2018). The interlocutors need to know the knowledge of euphemism to represent a flight to comfort, and it can be an alternative way to reduce tension when communicating even though they discuss taboo topics. Students adoring the taboo words can apply euphemism as a substitution. However, they should seek much information about it through media in order to comprehend how to use it in social communication. Euphemism can soften the rude words, smooth out the rough, change what is negative sounds positive. It also creates different nuances and eliminates fizziness in conversation although students talk about death, abortion, or sex. The communicators will welcome euphemism words since it does not sound negative for them. For instance, when the students say about the children who were born from illegal 
THE STUDY OF TABOO AND EUPHEMISM ON THE ENGLISH DEPARTMENT STUDENTS IN UNIVERSITAS PAMULANG

Lire Journal (Journal of Linguistics and Literature) P-ISSN: 2598-1803 E-ISSN: 2581-2130 Volume 4 Number 1 March 2020

relationship, they will say "illegitimate children" instead of "children of sin". Moreover, they will say people are on the street instead of homeless.

Euphemism presents negative perception from others since they are reluctant to say the truth directly (Enright, 2014). Burridge (2012) has opposite opinion; he declares that the use of euphemism indicates the speakers respect others. It helps students know speakers' attitude and help them to enhance the variety of English language. In brief, having known euphemism in social context is very beneficial for students since the usage euphemism can create comfortable conversation in social situation, not harm others, and protect a group of people from misunderstanding.

Holder, cited in Jackova (2010) classifies euphemism into some categories: death, religion, politics, business, diseases and medicine, human body and sex, and addiction. Euphemism words connected with death are pass away, pass on the other side, pass over, black American, upper class, live the land of the living, go to heaven, go to our rest, go to a better place, sleep away, return to ashes and other words. Euphemism words connected with religion (fear of evil) are black gentleman, black prince for Devil, good folk or neighbors. Business has also some euphemism vocabulary relating to unemployment, jobs, banking and other business topics. Uttering reduction in force, relieve, redundant, to reduce the headcount, to be selected out, or to seek fresh challenges is more polite instead of unemployment or loss of job, and uttering exterminating engineer instead of rat catcher. For the euphemism connected to diseases, people are suggested to utter off your trolley, off your tree, off your rocker, off your napper, off your head, of your gourd, and off your wall instead of people who have serious mental illness. Euphemism words relating to human body and sex are good friend, mistress, mate, miss, boy/girl friend to substitute a sexual partner. For sexual act, people are suggested to utter get busy with, get into bed with, get your share, get your green. Uneducated people sometimes utter lavatory room; they can substitute that word with powder room, private office, rest room, smallest room, hygiene facilities, or toilet. The last classification is euphemism for addiction. Students are able to be introduced with some euphemism words in gambling like play or game, and for the gamblers, they can utter bookmakers, commission agents, or turf accountants, and for the machine, they can say fruit machines. For the alcohol 96

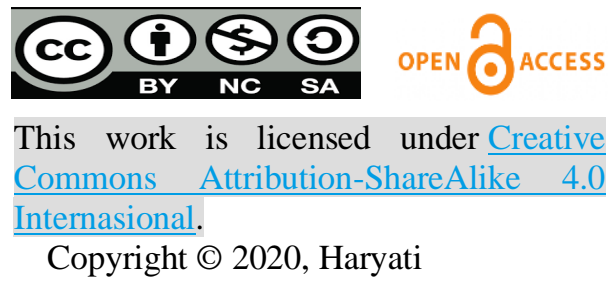


addiction, student learn to say have a drink, drink a lot, drink some or drink too much. The expressions for alcohol are bottle, cocktail, shot, snort, sip, tip, spot, plasma, or transfusion. Therefore, knowing the euphemism vocabulary is necessary for the students in order to enrich their vocabulary diversity. Also, they are able to use those words in proper social situation, not harm other interlocutors, and show off their respect and good attitudes as educated students.

\subsection{Taboo and Gender}

In this era, females and males have the same responsibilities and activities. Sometimes, women tend to be men in languages; they imitate how the men speak in social context. "Women adopt the typical male pattern of forbidden language use for their own purposes" (Spears, 1992). Timothy (1999) also recorded the kinds of taboo language used by females and males. Females uttered bustard and bitch, and male uttered gay, slut, and cunt.

Some researchers have conducted their studies to find out the relationship between gender and taboo words. Lakoff (2004) explained that women's language is correct, cooperative, powerless, lady talk, and not supposed to talk rough like men do. Women tend to sound something indirectly like requesting, asking, and others; they also avoid strong swear words like fuck, damn, shit. Women also speak properly, use euphemism more often to have comfortable conversation and not harm someone.

In addition, Coates (2004) adds his explanation about gender and taboo language. He reveals that the biological features of female and male are different, and they have differences how to talk something. The differences are affected by social surrounding. Women are more polite than men, indirect speakers, cooperative in social interaction. For instance, to ask something, women tend to use indirect speech acts and give the compliment for others. Male are more impolite, direct speakers, and competitive. They speak to the point and not walk around the bush. Men will show their power by strengthen their voice, and female refers to solidarity and support others. In conclusion, female and male show their differences in language and characteristics. They will apply their own characteristics in social situation. Women prefer speaking properly, politely, and indirectly to express their meaning to others. On the other hand, males have distinctive 
THE STUDY OF TABOO AND EUPHEMISM ON THE ENGLISH DEPARTMENT STUDENTS IN UNIVERSITAS PAMULANG

Lire Journal (Journal of Linguistics and Literature) P-ISSN: 2598-1803 E-ISSN: 2581-2130 Volume 4 Number 1 March 2020

characteristics in conversation. They refer speaking directly, impolitely, and bluntly to express their meaning and emotion.

\subsection{Euphemism and Gender}

Euphemism is belonging to women's words in social situation. It seems to replace embarrassment and impoliteness in societies. Furthermore, it is used to protect someone or a group of people from shame and guilty feeling. Rosadi, Rosa, \& Tiarina (2013) reveal that male prefer saying "semok" in Bahasa instead of fat, and females say "chubby" to refer the same word. Females also keep politeness in their speech acts in order to change the negative words to sound positive. In addition, Sari, Refnaldi, \& Rosa (2013) also reveal the same result. They found that euphemism is used in politic field to cover the situation like political issues. Also, euphemism can be seen in a family. For instance, parents teach their children about one of sensitive organ of male. Parents use euphemism word to cover sensitive word. They do not introduce "penis", but they introduce "small bird" to their children (Abbou \& Baider, 2016). Talbot classifies some feminine words like divine, adorable, charming, passed away instead of died, put down instead of killed. The phrases are "oh dear, you have put the peanut butter in the fridge again instead of "shit, you have put the peanut butter in the fridge again. Moreover, Else-Quest \& Shibley, (2018) state that women use euphemism frequently and comfortably, and they try to utter appropriate words in conversation.

\section{METHODOLOGY}

\subsection{The Approach of the Research}

This study used descriptive qualitative approach. Stake (2010) defines the qualitative research relies on human perception about the subjects and understanding." It is a kind of social study which collects data without considering the numerical results, and it helps people understand social condition. This study used qualitative approach since it focused on subjective in nature. It includes some aspects like attitudes, gender, perception, and others (Neville, 20017). Furthermore, the type of this study is in the form of description of the data and result, opinion, and observation rather than numerical data. 


\subsection{Participants}

The participants of this study are the undergraduate English department students of Universitas Pamulang who learn public speaking at the fifth semester (5 Morning classes). The total of the participants is 140 students. Some certain reasons why the writer selected the participants are the writer has taught them for several semesters and become familiar with their speaking ability. For the study, the participants from 5 different classes were selected by using purposive sampling. They were selected through some categories: students are able to speak English fluently, they have no lack of English vocabulary, they are familiar with some swear and slang words, and they have the diversity of attitudes. Purposive sampling is conducted in order to gain representative data, and the study will show the significant result. Therefore, the writer selected 40 students from regular morning classes to support this study.

\subsection{Procedures of the Study}

In obtaining the data, the writer used the students' English conversation in the classroom and distributed the questionnaire to seek the main factors of using taboo and euphemism in their conversation. For the conversation, the writer instructed the students to make daily conversation by having free topics. Talking free topic is supposed to express a lot of ideas in the students' conversation. They can discuss any topics in their conversation. During the students' conversation, the writer observed and noted several taboo and euphemism utterances.

After performing the conversation, the writer distributed the questionnaire to the students to answer the stated questions. After gaining all data, the writer analyzed and interpreted the result descriptively, and the result of the questionnaire could reveal the certain factors of producing taboo and euphemism utterances.

\section{RESULTS AND DISCUSSION}

The writer classifies the taboo words and euphemism based on the theory of several experts (Rahardjo, 2002, Suprapti, 2007, Formkin, 2005). After having the observation on the students' conversation, the brief finding is explained as following: 
THE STUDY OF TABOO AND EUPHEMISM ON THE ENGLISH DEPARTMENT STUDENTS IN UNIVERSITAS

PAMULANG

Lire Journal (Journal of Linguistics and Literature) P-ISSN: 2598-1803 E-ISSN: 2581-2130 Volume 4 Number 1 March 2020

\section{Dialogue 1 (Males)}

B: It is not your business. You just need to step back away, or I'll kick your ass.

A: Don't be so rude to the girls, or I'll report this to the lecturers, and you will be punished.

This conversation contains taboo word; the taboo phrase is "kick your ass". It refers to the use of taboo word in social interaction (Rahardjo, 2002). It is deliberately used to mock someone or other people. It also shows that the words seem to intimidate others, and intimidation is not allowed in each social context. "A" uttered this taboo word to show that he was mad, he didn't want anyone else interrupted what he was doing at that time, and he wanted to show his arrogance and power as a man. The reason of speaker uttered is to strengthen his anger to his friend and to show his power to another.

\section{Dialogue 2 (Males)}

A: I do fell it, and I had ever got it before. But you are a man. It is illogic if you cry a lot due to that girl. It seems you are homo.

This second conversation also delivers the use of taboo word; it is homo. It is the abbreviation of homosexual. Many university students use clipping words in their conversation since it is simple to utter. They do not need to utter a complete word, but it will deliver a complete idea like professor to be prof, laboratory to be lab, and other clipping words. In this conversation, "A" uttered impolite word since it is so sensitive word that make others angry and shy. In addition to the sensitive word, in social context, gender is divided into two sexes: male and female. Homosexual is not included in both male and female; hence, it creates shyness to someone. You seem a homo seems so private and sensitive statement since it is related to biological appearance. The word is not accepted in social conversation as one particular culture will ignore this word especially the eastern culture and religion. One specific reason why he uttered home because he just knows this word to refer couples who have similar sexual interest. Homo is one of the restrictions on sexual activities and relationship (Suprapti, 2007).

100

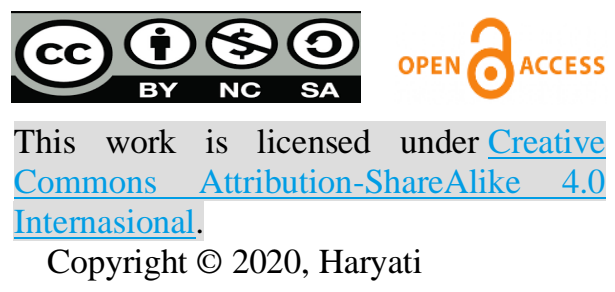




\section{Dialogue 3 (Females)}

Situation: in the job interview

B: I am Tri Hapsari. I am 20 years old, and I live in Ciledug. I graduated from Universitas Pamulang in 2018 majoring in English Literature. I have some major strengths and weaknesses. My strengths are workaholic and able to work under pressure. Besides, my weaknesses are I am a reckless person and sensitive person. However, I am able to solve those problems by joining some soft skills in some credible institutions. I am a married woman with 2 daughters, and I am from disability family.

\section{A: I see..Do you mean that one of your parents is a special need}

In that job interview, "B" explained himself by uttering taboo expression "I am from disability family". The word disability represents to someone who gets illnesses or one of the parts of body disable to work or do some routine activities. This word seems offensive and make others think negatively, or it is called as vulgarity (Suprapti, 2007). In addition to the taboo word, the conversation has one euphemistic word "special need". In this context, the first speaker deliberately substituted the word "disability" with "special need" in order to avoid the feeling guilty or soften the utterances. Surprisingly, the second speaker also comprehended the word special need; it means he knows both words, but she is not able to specify the proper word in the polite situation she had at the time. On the other hand, the first speaker was able to apply the polite word in particular situation like job interview in order to have disrespectful word. For this case, one speaker was able to switch one taboo word with one appropriate word since she knows the idiomatic expression of disability.

\section{Dialogue 4 (Female)}

B: I think you already know he is from working class family, and he is one of the bread winners in his family.

This conversation represents the example of euphemism in social interaction. The second speaker uttered working class to classify the status of someone. Working class is a word that represents to poor or low-income person. This word is used to hide or to soften the utterance in conversation. 101

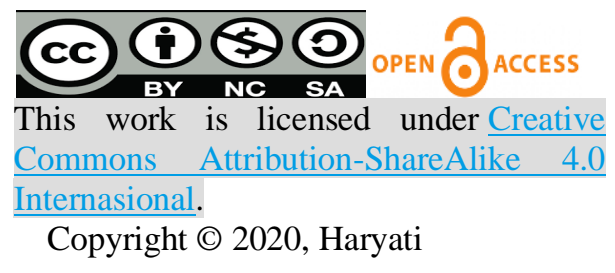


THE STUDY OF TABOO AND EUPHEMISM ON THE ENGLISH DEPARTMENT STUDENTS IN UNIVERSITAS

PAMULANG

Lire Journal (Journal of Linguistics and Literature) P-ISSN: 2598-1803 E-ISSN: 2581-2130 Volume 4 Number 1

March 2020

she wanted to avoid feeling guilty or hurt someone. Therefore, the content of conversation runs smoothly. She was able to choose working class as the euphemism word since she had ever learned about some classes in societies. Thus, she tried to apply that word in social interaction, and she wanted others know that she had updated word.

\section{Dialogue 5 (Male)}

B: I will be responsible if I made any mistake, but in this case, I crushed your car since you did not give any sign to turn left, so I did not see any sign given to you. It was not my fault.

A: So, you do not want to give some money to fix it

B: Of course, not

A: Damn, what irresponsible person you are!

The second speaker uttered one taboo word to express his anger and annoyance. He felt so mad, so he used taboo word to express and strengthen his emotion to his interlocuter. The use of taboo word can cause the conversation messy. The conversation reveals obvious meaning that it was uttered since the speaker got disturbance or dissatisfaction from another. Hence, spontaneously, people can utter this to show that he is mad or feels inconvenience. Some other factors are people utter this taboo word to insult, to curse, and to symbolize his anger. Sometimes, the utterance is supported by behavioral violence, so it creates misunderstanding and messy. In addition to those factors, damn can break culture since it is impolite in society; people can utter this in any places to anyone he hates without differing the age of someone. Rahardjo (2002) summarizes that "damn" has been familiar in English speakers; therefore, many people know and utter that word.

\section{Dialogue 6 (Female)}

A: The police officers got rid of the hostess in some urban areas, and they gave various reactions. Some of them ran away from them, and others could not do anything.

B: They deserved it

The conversation presents the taboo word, hostess. This word does not seem a negative word in English society since it represents to those who welcome and serve dinner for others, but it is one 102

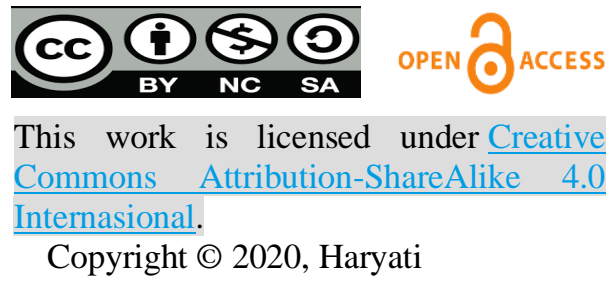


of taboo words in Indonesia. Many Indonesian students think that hostess is woman who receives or entertains guests. However, it delivers another meaning which refers to woman whose appearance sexual behavior which are not respectable (Suprapti, 2007). Another assumption is to disrespect or to mock people who break the norm or value in society. In this conversation, the certain factor why the speaker uttered "hostess" because they did not know any proper word to mention the women who work for prostitution.

\section{Dialogue 7 (Female)}

B: What test will you have?

\section{A: IELT}

B: Oh my gosh, you will have IELT.

A: Yup, I have a plan to work in Aussie, and you know that there will be many requirements for that. Now, I am processing for it.

B: I see...but joining IELT need more preparation

A: Yes, of course, I have already finished my courses

This conversation contains the word gosh as taboo word. Gosh is a taboo word that refers to the god. Many young and adult learners use this word in their daily conversation. They utter it since it is simply to utter and not too formal for them. However, in the religious matter, it is one of taboo words; religion has its own rule to call the god, and it cannot be changed to another word. Formally, God can be changed to be Jesus, Allah, and others. Substituting the name of God with gosh is taboo word related religion (Rahardo, 2002). The speaker uttered gosh since she knew that it is uttered by many people in social media, and the word seems cool to listen.

\section{Dialogue 8 (female)}

A: What topic should you discuss?

B: Abortion. I have no ideas about it. I just search, but I don't get the ideas.

A: Why don't you try to find out the doers of abortion in your neighborhood. You can have an interview then. I think it is not difficult to do.

B: Are you sure that I should it. As I know, it is so private question. Each won't explain it vulgarly 103

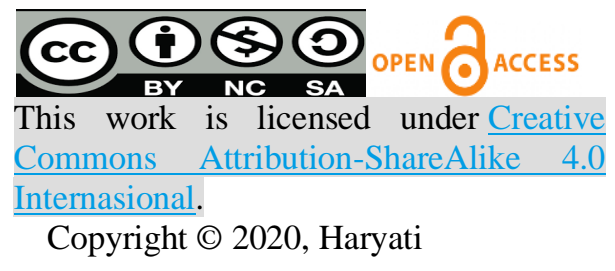


THE STUDY OF TABOO AND EUPHEMISM ON THE ENGLISH DEPARTMENT STUDENTS IN UNIVERSITAS PAMULANG

Lire Journal (Journal of Linguistics and Literature) P-ISSN: 2598-1803 E-ISSN: 2581-2130 Volume 4 Number 1 March 2020

The participants in the conversation discussed abortion as an issue. It is clear that abortion is one of examples of taboo words. Obviously, abortion is an illegal activity which has deliberate purpose to end the pregnancy by removing the embryo before one baby survives. According to Freud as cited in Suprapti (2002), it is one of the sensitive issues in every country since it is related to killing a baby, and abortion is claimed as restrictions on state of genitalia (bodily pain or medical surgery). To substitute the word abortion, people or students can use terminating a pregnancy in order not to hurt someone or to give unpleasant expression. This word also can soften the conversation and not lead the misunderstanding among speakers. The writer found out the factor of uttering this taboo word. Both speakers repeatedly uttered abortion in their conversation as they do not have any appropriate word to substitute the word abortion. They exactly know that abortion is a sensitive topic in society, but they think that it is a common utterance now. Also, both speakers are only classmates who discussed one topic, and they didn't involve other people. Therefore, they thought that they didn't break any rules of language use.

\section{Dialogue 9 (Female)}

\section{B: Thanks}

Oh ya $\mathrm{Zi}$, If you don't mind, please come to my house tomorrow. After my father passed away, my Family will have syukuran for praying him.

A: What time's it?

B: It is about $7 \mathrm{pm}$

\section{A: I will come}

The second speaker delivered one euphemistic word. She uttered passed away to substitute the word died. Actually, there are so many words that refer similar meaning like die, pass away, go to heaven, go to glory, rest in peace and others. The use of pass away as the euphemism can replace a fear since many people claim that death is something frightened and not everyone loves talking about this topic. Passing away can also avoid giving unpleasant expression and neutralize the conversational conversation (Wilson as cited in Mahmuda, 2003). The factor of the second speaker used a kind of euphemism since she knows how to use proper word in one particular situation, and 104

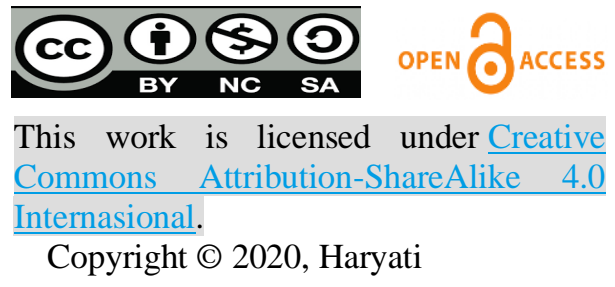


she also tried to make a polite conversation. In addition to create a polite conversation, she has got the knowledge that pass away is more polite than die.

\section{Dialogue 10 (Male)}

A: How about the black people? Were they accepted as the immigrant there?

B: Big NO. They became slaves at that time. They did not have any shelter, the women were forced to join the prostitution, and the children did not get any education and other facilities like public toilet, public transportation, and others.

A: How poor niggers were! But, America in the modern era had ever had the first president from Black American.

B: You are right, the black Americans do not have any racial discrimination anymore. They can star some movies, be everything they want, and many others.

A: The discrimination is still existing there, but it is done by only few individuals

This conversation presents both taboo and euphemism. The speakers blended them unconsciously. The taboo words are toilet and niggers, and the euphemism is black Americans. The use of nigger refers to black man; it is taboo as it refers different race and minority. In public assumption, nigger is a person or community that has less numbers in one country, lack of educational background, lower family class, no shelters, poor social background, and other negative things. The assumptions lead many people to have negative opinions about Black people. Also, the word "nigger" shows their real identity since the white people gave the nigger as their nick name; therefore, it is so sensitive and able to hurt them. However, one student also uttered one euphemism word. He uttered black American to refer nigger. Black American is the euphemism of nigger since it refers to one of races living in America. It is also a symbol of racial assimilation which means the people have assimilated their own culture; hence, it is a polite word for black people. Moreover, toilet is a taboo word. Based on the observation of the writer in the classroom, many students utter toilet when they ask the permission to go there. It occurs routinely when they are joining the lecture. In fact, the lecturers do not give any kind of suggestion to use another word to replace the 105

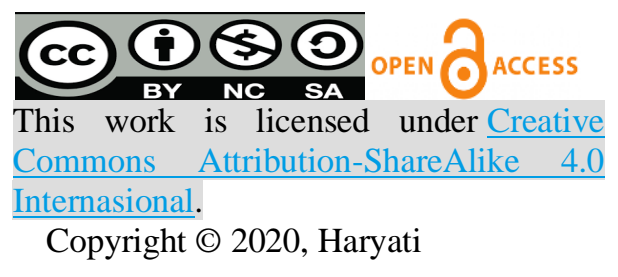


THE STUDY OF TABOO AND EUPHEMISM ON THE ENGLISH DEPARTMENT STUDENTS IN UNIVERSITAS

PAMULANG

Lire Journal (Journal of Linguistics and Literature) P-ISSN: 2598-1803 E-ISSN: 2581-2130 Volume 4 Number 1 March 2020

word toilet. Woods (2008) highlights that the utterance of toilet can be replaced by restroom or comfort station. These words seem polite instead of toilet.

\section{Dialogue 11 (Male)}

A: Will you apologize him?

B: No, I cannot do that bloody stupid thing

A: We have been friends since we were at schools. Give him the chance!

B: Let's see

The above conversation presents bloody as taboo word (Rahardjo, 2002). It is one of aggressive words to stress a statement or an annoyed statement. The speaker uttered this word to emphasize his anger to his friend, and he wanted to clarify that he did not want to give any chance; therefore, to show his anger, he uttered bloody. At the beginning, the writer could not find any taboo word, but she relistened the conversation, it is found that bloody is one example of taboo word used to express annoyance. The students have one specific reason why they apply bloody in their conversation; it is used to strengthen one's anger to someone. They know the word from their habit watching YouTube, and they listen to many mad expressions.

\section{Dialogue 12 (Male)}

B: I see...I had ever submitted the previous project late, and he told me that I was idiot person. It hurt me a lot, but I know that it was my fault. Sometimes, his utterances seem offensive, so every student who make a case with him do not want to redo the same problem.

A: What idiot you are, did he mock you?

B: Just forget it

\section{Dialogue 13 (Male)}

B: I face some problems living here like the electricity, lack of clean water and others.

A: I see...so, when will you move then?

B: Soon. I think I will be an idiot man if I stay here for long time. stupid 106

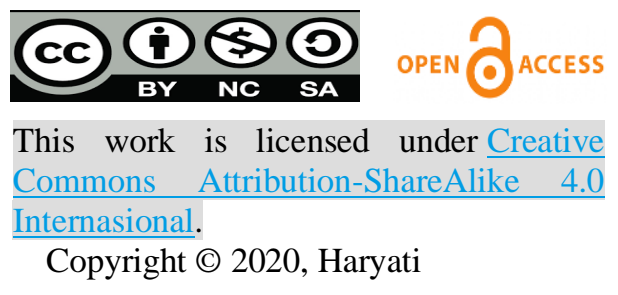


Dialogue 12 and 13 have one similar taboo word. Many students say idiot or stupid because they were introduced by those word in the early educational level. Besides, they are more familiar with many slang words instead of polite words. This word is used to mock someone about his disability of doing something. The utterance of idiot leads to feeling guilty of someone. He will underestimate himself and think he is more stupid than others. It also encourages him to be hopeless person and gives the effects on his psychology. Lacking vocabulary leads to the use of this taboo word; they do not have any proper word to substitute the taboo word. In fact, idiot can be substituted by thoughtless person or senseless person. Actually, these words seem more polite instead of saying idiot.

\section{Dialogue 14 (Female)}

B: It's true. Do you know my next door who studies in UIN? She is so interested in reading any kinds of novel.

A: I know her. I have ever met her once when I visited your house. She is a girl who has four eyes, isn't she?

In this dialogue, one speaker uttered four eyes which refers to someone wearing glasses since she has a problem with minus eyes. Actually, four eyes are taboo word used to mock someone with joking. This word becomes taboo since it is related to human organs. It is commonly used by students to express someone's disability. Moreover, "words relating to sex, sex organ, and natural bodily functions make up large part of the taboo words of many cultures" (Fromkin, 2005). This utterance is spoken to show inappropriate joke to someone; as a result, she expresses something with little worth.

\section{Dialogue 15 (Male)}

B: I think she won't bring it now. You really know her; she looks like a story teller.

A: I don't think so. I believe her because she is not a liar.

In this conversation, the writer found one euphemism and one taboo word. The first speaker uttered liar as taboo word. It is spoken to express someone who tells half-truth. This word leads to 107

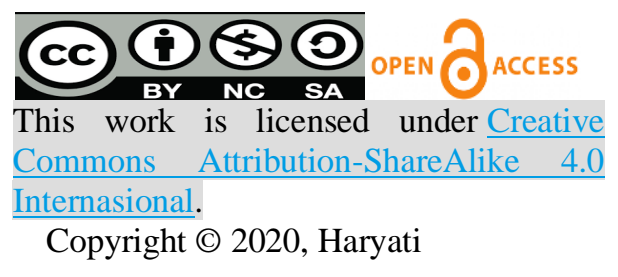


THE STUDY OF TABOO AND EUPHEMISM ON THE ENGLISH DEPARTMENT STUDENTS IN UNIVERSITAS

PAMULANG

Lire Journal (Journal of Linguistics and Literature) P-ISSN: 2598-1803 E-ISSN: 2581-2130 Volume 4 Number 1

March 2020

misunderstanding among speakers because this taboo word accuses someone tells untrue information. It is also sensitive word and relates to decline someone's pride.

\section{Dialogue 16 (Female)}

\section{A: Look! The fatty is coming.}

B: Don't say it loudly. I am afraid if she hears you.

A: Just kidding. I think it is funny if we call her fatty instead of fat.

B: But...she will be mad because you try to mock her

A: I know..I am wrong. I won't repeat that word anymore. Are you satisfied now?

B: Good point...I suggest you to say proper word to replace fatty.

This conversation contains fatty from fat word. It was uttered by one speaker because it would be shocked by the listener, and it will cause someone feel embarrassed. From feeling embarrassed, the target person probably will be disappointed if someone mocks about someone's abnormal physical. If people discuss someone appearance, it will be so sensitive topic; hence, the speaker should find another proper word to substitute that word in order not to hurt someone else. Furthermore, for a woman, fatty is so harsh word which is able to make her loose her selfconfidence to socialize among societies.

\section{CONCLUSION}

In brief, the above findings of taboo and euphemism words reveal that the male students preferred uttering taboo words instead of euphemism since they wanted to show their own identity by uttering some familiar words. They found those words through some digital media; gadget, online games, and you tube play crucial roles in their vocabulary achievements. Actually, some offensive words are uttered when people feel mad and express emotion; however, the male students also uttered taboo words when they were not in heated arguments. The best reason from them was they wanted to be cool when they uttered it. In this case, the male students could not classify the situation in societies. On the other hand, the female students preferred uttering more euphemism words than taboo words. Although they uttered taboo words, they did not know the appropriate 108

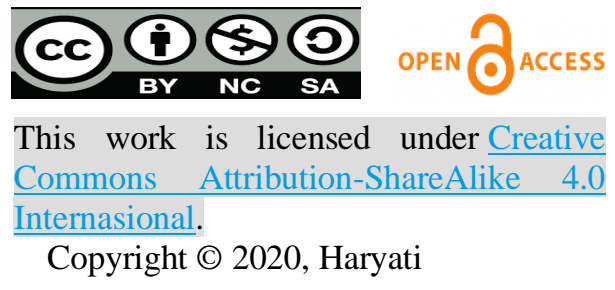


words for sensitive topic. The lack of vocabulary became the major factor why the female students uttered taboo words. However, they still focused on using polite words in any kind of conversational situation. As a consequence, they could respect themselves and others by utter polite words, and they explained that to respect others, they needed to use polite words. Therefore, the conversation would run smoothly and avoid misunderstanding in social communities.

The writer draws the suggestion for the further researchers, teachers, students, and institution. For the further researcher, they should do similar research on taboo and euphemism for deeper examination. Besides, the teachers have to introduce the diversity of words like taboo and euphemism to be conducted in social conversation. For the English department students of Pamulang University, they should learn and comprehend more many taboo and euphemism words to improve their vocabulary achievement. Hence, they know the words use in formal and informal situation. The last, Universitas Pamulang as the institution and others should be the facilitator for teachers and students to provide English seminar to enhance the students' comprehension of taboo and euphemism word in social interaction among societies

\section{ABOUT THE AUTHOR}

The writer is one of the English lecturers in Univeristas Pamulang. She has been teaching for several years. She has strong eagerness in writing module and participating in national international seminars; therefore, she has already published her research paper into journal and proceeding. She is also interested in analyzing applied linguistics. 
THE STUDY OF TABOO AND EUPHEMISM ON THE ENGLISH DEPARTMENT STUDENTS IN UNIVERSITAS PAMULANG

Lire Journal (Journal of Linguistics and Literature) P-ISSN: 2598-1803 E-ISSN: 2581-2130 Volume 4 Number 1 March 2020

\section{REFERENCES}

Abbou, J \& Baider, F. (2016). Gender, language, and the Periphery. Philadelphia: John Benjamins Publishing Company.

Abidin, Z. (2003). Euphemism expression used in Kompas during Word War Cup 2002. Thesis. Malang.

Burridge, K. (2012). Euphemism and language change: The sixth and seventh ages. Lexis. Journal in English Lexicology (7).

Coates, J. (2004). Women, men and language. 3rd edition. Harlow: Pearson Education

Ekstrom, A. (2008). Taboo Language in sex and the city: An analysis of gender differences in using taboo language in conversation. Kristianstad University.

Else-Quest, N \& Janet, S.H. (2018). The psychology of women and gender. USA: SAGE Publication.

Enright, D. (2014). In other words. London: Michael O’Mara Books Limited.

Fromkin, V. (2005). An introduction to language. United State of America: Pearson Longman

Habibi, A \& Rizky, K. (2018). Euphemism and gender: The euphemism used by male and female in Minangkabau songs. Proceeding of the 1st Annual International Conference on Language and Literature, Fakultas Sastra, UISI, Medan.

Jackova, M. (2010). Euphemism in today's English. Tomas Bata University in Zlin Faculty of humanities.

Lakoff, R.T. (2004). Language and woman's place. Text and Commentaries. Edited by Mary Bucholtz. Oxford: Oxford University Press.

Mahmuda, L. (2003). Taboo utterances expressed in "American Pie". Thesis. Malang

Nababan, P.N.J.(1987). Ilmu pragmatik (Teori dan penerapannya). Jakarya: PPLPTK.

Neville, C. (2007). Introduction to research and research methods. Bradford University.

Rahardo, M. (2002). Pengantar Penelitian Bahasa. Malang: Cendikia.

Rosadi, Rusdi,N.R., \& Yuli, T. (2013). Differences in euphemism used by male and female Minangkabaunese. English Language and Literature E-Journal, p.121-131

110

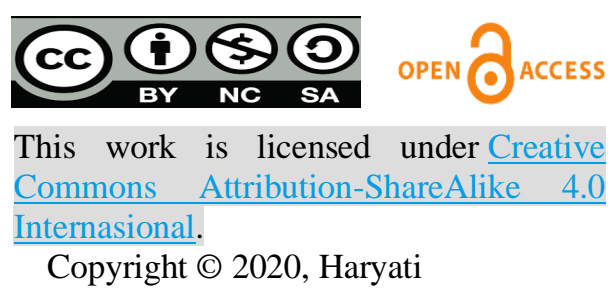


Sari, D.M., Refnaldi \& Rusdi, N.R. (2013). Euphemism used in language of politic in Padang express newspaper. Journal of study Bahasa and Sastra Inggris, p.31-40.

Spears, R. A. (1992). Forbidden American English: A series complication of taboo American English. Illinois USA: Passport Books.

Stake, R. E. (2010). Qualitative Research. London: The Guilford Press.

Suprapti, M. (2004). Terjemahan Riyadus Sholihin. Semarang: P.T. Karya Toha Putra.

Timothy, J. (1999). Why we curse: Philadelphia, PA, USA: John Benjamin Publishing Company. Retrieved August, 2019 from http://site.ebrary.com.ezproxy.bibl.hkr.se/lib/kristianstad/top.

Wibowo, H.T.A. (2008). A study of taboo words and euphemistic expressions of Ali G film. Thesis. Malang.

Woods, E. M. (2008). Sightseeing. New York: Bloomington. 